Jurnal Keperawatan Silampari

Volume 3, Nomor 1, Desember 2019

e-ISSN :2581-1975

p-ISSN :2597-7482

DOI: https://doi.org/10.31539/jks.v3i1.772

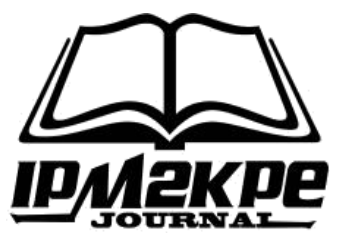

\title{
PENGARUH KEARIFAN PANGAN LOKAL SUKU REJANG TERHADAP PENANGANAN STUNTING BADUTA DI BENGKULU UTARA
}

\author{
Danur Azissah Roesliana Sofais ${ }^{1}$, Berlian Kando Sianipar ${ }^{2}$, Darmawansyah $^{3}$ \\ Program Studi Keperawatan, Universitas Dehasen Bengkulu ${ }^{1,2,3}$ \\ d.azissah@yahoo.com ${ }^{1}$
}

\begin{abstract}
ABSTRAK
Penelitian ini bertujuan untuk mengidentifikasi pengaruh kearifan pangan lokal suku rejang terhadap penanganan stunting baduta di Bengkulu Utara. Desain penelitian menggunakan quasy-experiments study, one group of stunting babies (height-for-age zscore <-2) yang berusia 12-24 bulan pada 36 responden. Hasil penelitian menunjukkan bahwa ada perubahan tinggi badan baduta stunting setelah dilakukan treatment weaning pada baduta dengan nilai mean pre-test: 69.61 dan mean post-test: 77.16, nilai korelasi $>0.05$ (0.846). Dengan demikian dapat disimpulkan bahwa Treatment dalam pemberian weaning pada baduta stunting menggunakan kearifan pangan lokal bersifat positif dapat meningkatkan tinggi badan secara bermakna.
\end{abstract}

Kata Kunci : Pangan Lokal, Stunting, Treatment

\section{ABSTRACT}

The purpose of this research is to identify the effect of local food wisdom of Rejang trait to treat stunting infant at North Bengkulu. The design of this research is using queasyexperiments study, one group of stunting babies (height-for-age z-score < -2) consists 36 respondents with 12-24 months old. The result of this research shows that there is a change on stunting infant height after weaning treatment with mean score pre-test: 69.61 and mean for post-test: 77.16 . correlation score $>0.05$ (0.846). It means that giving weaning treatment for stunting infant by using local food wisdom is positive. It can increase height gradually.

Keywords: Local Food, Treatment, Stunting

\section{PENDAHULUAN}

Stunting adalah kondisi gagal tumbuh pada anak balita akibat kekurangan gizi kronis sehingga anak terlalu pendek untuk usianya atau otak tidak berkembang dengan baik. Seorang anak dinyatakan Stunting apabila indeks panjang badan dibandingkan dengan umur $(\mathrm{PB} / \mathrm{U})$ atau tinggi badan dibandingkan dengan umur $(\mathrm{TB} / \mathrm{U})$ dengan batas (z-score) kurang dari -2 SD (WHO, 2015; BKKBN, 2018).

Stunting menjadi masalah yang besar karena berkaitan erat dengan indikator kesehatan. Pembangunan kesehatan periode 2015-2019 salah satunya difokuskan pada program prioritas yaitu penurunan prevalensi balita pendek (Stunting) (Kemenkes RI, 2018; WHO, 2015).

Di Indonesia, sekitar 37\% (hampir 9 Juta) anak balita mengalami stunting (Riset Kesehatan Dasar/Riskesdas 2013). Indonesia adalah negara dengan prevalensi stunting 
kelima terbesar. Balita/Baduta (Bayi dibawah usia Dua Tahun) yang mengalami stuntingakan memiliki tingkat kecerdasan tidak maksimal, menjadikan anak menjadi lebih rentan terhadap penyakit dan di masa depan dapat beresiko pada menurunnya tingkat produktivitas. Pada akhirnya secara luas stunting akan dapat menghambat pertumbuhan ekonomi, meningkatkan kemiskinan dan memperlebar ketimpangan (TNP2K, 2017).

Stunting tidak saja berdampak pada anak yang mengalaminya saja. Namun dampaknya sangat luas, pada tingkat individu stunting berdampak pada terhambatnya perkembangan otak dan fisik, rentan terhadap penyakit, ketika dewasa mudah menderita kegemukan sehingga rentan terhadap berbagai penyakit termasuk penyakit tidak menular serta sulit berprestasi sehingga daya saing individu rendah. Di tingkat masyarakat dan negara, stunting mengakibatkan bertambah sumber daya manusia yang tidak produktif yang dapat menyebabkan turunnya daya produktivitas dan memiliki efek menghambat pertumbuhan ekonomi, meningkatkan angka kemiskinan dan kesakitan sehingga beban negara meningkat, ketimpangan sosial dan menurunkan daya saing dengan negara lain (BKKBN, 2018; Senbanjo, 2011; Martorell 2010).

Provinsi Bengkulu mengalami permasalahan kesehatan di aspek pertumbuhan dan perkembangan pada Balita, dimana kasus stunting di Provinsi Bengkulu tahun 2016 sebesar 22,9\% dan terjadi peningkatan tahun 2017 sebesar 29,5\%. Di Provinsi Bengkulu kasus stuntingtertinggi ketiga terjadi di Kabupaten Bengkulu Utara sebesar 35,8\% dibandingkan dengan Kabupaten yang lainnya (Dinas kesehatan provinsi Bengkulu, 2018).

Upaya menghadirkan generasi emas dibayangi kehadiran stunting yang masih mengancam. Stunting merujuk pada kondisi tinggi anak yang lebih pendek dari tinggi badan seumurannya. Stunting terjadi lantaran kekurangan gizi dalam waktu lama pada masa bawah dua tahun (baduta). Cara untuk menghindarkan anak dari kasus Stunting adalah melalui penerapan strategi percepatan penurunan stunting dengan pemberdayaan masyarakat dalam pemberian pangan yang kaya akan zat gizi (BKKBN, 2018).

Intervensi gizi spesifik dengan sasaran Ibu menyusui dan anak usia 7-23 bulan merupakan bagian dari kerangka intervensi stunting yang telah dilakukan oleh pemerintah (TNP2K, 2018). Intervensi ini meliputi kegiatan untuk mendorong penerusan pemberian ASI hingga anak/bayi berusia 23 bulan. Kemudian, setelah bayi berusia diatas 6 bulan didampingi oleh pemberian MP-ASI.

Kabupaten Bengkulu utara merupakan kabupaten yang mayoritas masyarakatnya suku rejang yang sangat kaya akan pangan kearifan lokal. Pemanfaatan pangan lokal suku rejang ini dipilih sebagai tindak lanjut dari program pemerintah dalam penanganan stunting pada Intervensi Spesifik. Banyak bahan pangan lokal yang dihasilkan masyarakat setempat akan tetapi pemanfaatan pangan lokal tersebut belum di terapkan dalam weaning infant untuk menekan jumlah atau angka prevalensi stunting di kawasan kabupaten Bengkulu Utara.

Penggunaan kearifan pangan lokal merupakan hal yang bagus untuk weaning infant dikarenakan tidak memiliki efek samping, murah, mudah di kembangkan dan bernilai jual. Selain itu, riset atau penelitian yang melibatkan pangan kearifan lokal tergolong masih sedikit dan menjadi media pengembangan penelitian kesehatan yang menarik dan dapat dikaji secara lebih lanjut.

Pangan kearifan lokal suku rejang adalah bagian tak terpisahkan dalam budaya masyarakat Bengkulu Utara. Sebab nilai budaya lokal telah mengakar dalam kehidupan 
masyarakat. Pangan kearifan lokal memiliki banyak keuntungan, seperti: kemanan makanan yang terjamin atau tidak memiliki efek samping (safety food and security food), mudah diperoleh dengan biaya yang murah atau tanpa biaya pun (economic effecient), mudah di budidayakan, bernilai gizi yang baik dan dapat meningkatkan pendapatan rumah tangga (health economic). Pangan kearifan lokal merupakan salah satu alternative yang dapat di aplikasikan dalam menurunkan prevalensi stunting.

Pangan lokal yang dibudidaya oleh masyarakat rejang memiliki zat gizi yang tinggi baik makro maupun mikro. Pangan lokal ini banyak mengandung karbohidrat, protein, lemak, dan mineral yang sangat dibutuhkan untuk pertumbuhan dan perkembangan baduta. Salah satu pangan lokal suku rejang yang kaya akan protein adalah pemanfaatan belut sawah, ikan nila, nasi ketan dan sayuran hijau. Belut sawah dan ikan nila banyak tersebar di wilayah kabupaten bengkulu utara tetapi sampai saat ini belum dimanfaatkan secara maksimal oleh masyarakat tersebut. Begitu juga dengan banyaknya lahan pekarangan rumah yang banyak ditanami dengan tanaman hijau tetapi belum dimanfaatkan untuk kebutuhan sehari hari keluarga (bayam, kangkung, dan jagung).

Makanan pendamping ASI (MP ASI) merupakan makanan peralihan dari ASI ke makanan keluarga yang mengandung zat gizi, diberikan pada anak berumur 6-24 bulan untuk memenuhi kebutuhan gizinya selain dari ASI. Peranan makanan tambahan (weaning infant) sama sekali bukan untuk menggantikan ASI, melainkan untuk melengkapi ASI. Pengenalan dan pemberian MP-ASI harus dilakukan secara bertahap baik bentuk maupun jumlahnya, sesuai dengan kemampuan pencernaan bayi/anak. Dengan pemanfaatan kearifan bahan pangan lokal sesuai kebutuhan dan kemampuan pencernaan anak diharapkan dapat mencegah dan mengatasi stunting pada baduta.

\section{METODE PENELITIAN}

Desain Penelitian

Penelitian ini menggunakan desain penelitian eksperimen semu (Quasy experiment study) dengan menggunakan rancangan One group pre and post test design.

\section{Participant}

Populasi pada penelitian ini adalah baduta berusia $12-24$ bulan yang mengalami stunting, memiliki tinggi badan dengan nilai $z$ score untuk indeks $\mathrm{TB} / \mathrm{U}<-2 \mathrm{SDdan}$ berada di Wilayah Kerja Puskesmas Kerkap kabupaten Bengkulu Utara. Jumlah sampel dalam penelitian ini berjumlah 36 orang responden. Pengambilan sampel penelitian dilakukan dengan menggunakan teknik total sampling.

\section{Data Colection Procedure}

Sebanyak 36 responden dikaji kelayakannya dalam studi ini, dimana semua responden (orang tua baduta) setuju untuk berpartisipasi. Partisipan yang telah setuju untuk dijadikan responden mengisi dan menandatangani Informed consent dan mengisi seluruh kuisioner yang diberikan dengan jujur. Kemudian peneliti melakukan kunjungan kerumah responden. Intervensi diberikan selama 90 hari dimana pengukuran tinggi badan baduta dilakukan pada awal penelitian (pre test) dan setelah dilakukan intervensi pada hari ke 90 (post test). 


\section{Intervention Group}

Sebelum dilakukan ntervensi pada responden, peneliti terlebih dahulu melakukan pelatihan pada 12 orang kader puskesmas yang tinggal di 12 desa di wilayah kerja Puskesmas Kerkap. Selama Intervensi kader Puskesmas ini akan ikut membantu memantau dan mendampingi baduta stunting yang tinggal di wilayah tersebut. Selanjutnya peneliti melakukan pre test tinggi badan baduta yang menjadi responden penelitian. Intervensi dilakukan secara individual dengan terlebih dahulu mengajarkan dan melatih orang tua baduta tentang cara pengolahan bahan pangan lokal dan pemberian makanan lokal (bubur jagung tim dan sup belut sawah/sup ikan nila) yang nantinya diberikan kepada baduta selama intervensi penelitian. Makanan yang telah diolah diberikan 3 kali sehari dan diberikan selama 3 hari dalam satu minggusecara selang seling dengan jumlah makanan semangkok penuh $250 \mathrm{cc}$. Selama pemberian makanan tambahan ini, ASI tetap diberikan. Pengukuran tinggi badan setelah intervensi (post tes) dilakukan setelah hari ke 90.

\section{Ethical Consideration}

Penelitian ini dilakukan setelah mendapat persetujuan dari dewan peninjau etika atau telah lolos kaji etik di Universitas Bengkulu. Peneliti telah menjelaskan tentang penelitian ini kepada calon responden (orang tua responden) termasuk tujuan, metode, manfaat, resiko serta prosedur intervensi yang akan dilakukan selama proses penelitian. Peneliti menjamin kerahasiaan pada responden dan memberikan hak pada responden bahwa mereka bisa keluar pada saat proses penelitian kapanpun tanpa implikasi untuk perlakuan selanjutnya.

\section{Statistik Analisis}

Analisis yang digunakan dalam penelitian ini adalah analisis bivariat untuk menguji perbedaan tinggi badan baduta stunting sebelum dan sesudah dilakukan intervensi pemberian pangan lokal suku rejang. Penelitian menggunakan Uji $\mathrm{T}$ dependent, sebelumnya harus dilakukan uji normalitas data dengan uji wilcoxon, data berdistribusi normal apabila nilai signifikasi $>0,05$.

\section{HASIL PENELITIAN}

Karakteristik Responden

Table1

Distribusi Frekuensi Karakteristik Responden Stunting (n=36)

\begin{tabular}{ccc}
\hline Karakteristik & Jumlah & Persentase \\
\hline Usia Balita & & \\
$<18$ bulan & 23 & 63.9 \\
$\geq 18$ bulan & 13 & 36.1 \\
\hline Jenis Kelamin & & \\
Perempuan & 20 & 55.6 \\
Laki-laki & 16 & 44.4 \\
\hline Tinggi Badan Ibu & & \\
$<150$ cm & 19 & 52.8 \\
$\geq 150$ cm & 17 & 47.2 \\
\hline Pendidikan Ibu & & \\
SD-SMP & 17 & 47.2 \\
SMA/SMK-S1 & 19 & 52.8 \\
\hline
\end{tabular}




\begin{tabular}{ccc}
\hline Pekerjaan ibu & 32 & 88.9 \\
IRT & 4 & 11.1 \\
Swasta & & \\
\hline & & \\
Pengetahuan Ibu & 21 & 58.3 \\
Tidak baik & 15 & 41.7 \\
Baik & & \\
\hline
\end{tabular}

Berdasarkan tabel 1 dapat dilihat bahwa sebagian besar responden adalah baduta yang berusia di bawah 18 bulan (63.9\%) dan sebagian kecil berusia $\geq 18$ bulan (36.1\%). Hal ini sesuai dengan ketentuan kriteria inklusi dari sampel yang akan di ambil, yaitu usia 12-24 bulan. Dari sampel, sebagian besar berjenis kelamin perempuan (55.6\%) dan sebagian berjenis kelamin laki-laki (44.4\%), hal ini menunjukan bahwa jenis kelamin perempuan lebih dominan dalam kejadian stunting di wilayah kerja Puskesmas Kerkap Kabupaten Bengkulu Utara. Sehingga hal ini menjelaskan bahwa, jenis kelamin perempuan lebih berpontensial terkena stunting dibandingkan dengan jenis kelamin laki-laki.

Dari tolak ukur tinggi badan ibu baduta diperoleh bahwa sebagian ibu memiliki tinggi badan $<150 \mathrm{~cm}(52.8 \%)$ dan sebagian memiliki tinggi badan $\geq 150 \mathrm{~cm}(47.2 \%)$, hal ini menjelaskan adanya gambaran bahwa tinggi badan seorang ibu dapat berpengaruh terhadap pravelensi kejadian stunting pada baduta, semakin tinggi badan seorang ibu, maka akan potensi terjadinya stuting akan semakin kecil. Dari segi Pendidikan, diperoleh hasil bahwa sebagian ibu memiliki pendidikan SD-SMP (47.2\%) dan sebagian berpendidikan SMA/SMK-S1 (52.8\%), hal ini menunjukan pendidikan ibu masih tergolong rendah. Tingkat pendidikan dapat mempengaruhi tingkat pengetahuan seorang ibu. Semakin baik tingkat pendidikan, maka akan semakin baik pula pengetahuannya seorang ibu mengenai status gizi baduta, khususnya stunting. Dari segi pekerjaan diperoleh hasil bahwa sebagian besar ibu bekerja sebagai IRT (88.9\%) dan sebagian kecil bekerja di swasta (11.1\%). Sedangkan untuk pengetahuan ibu diperoleh bahwa sebagian ibu memiliki pengetahuan yang tidak baik $(58.3 \%)$ dan sebagian berpengetahuan baik $(41.7 \%)$

Tabel2

Tinggi Badan Pre-Test dan Post-Test Sebelum dan Setelah Dilakukan Intervensi $(\mathrm{n}=36)$

\begin{tabular}{|c|c|c|c|}
\hline Karakteristik & Mean & Korelasi & $\mathrm{p}$-value \\
\hline \multicolumn{4}{|l|}{ Uji t } \\
\hline Pre-test tinggi badan & 69.61 & 0.846 & $<0.001$ \\
\hline Post-test tinggi badan & 77.16 & & \\
\hline
\end{tabular}

Berdasarkan tabel 2 dapat dilihat bahwa adanya peningkatan antara pre-test dan post-test (mean pre-test: 69.61, mean post-test: 77.16), dimana nilai mean menunjukan peningkatan dan nilai korelasi > 0.05 (0.846) yang menyatakan bahwa adanya hubungan korelasi yang kuat dalam melakukan treatment weaning pada baduta dan memiliki signifikan ( $p$-value : <0.001). 
Tabel.3

Perkembangan Setelah Treatment pada Responden Stunting $(\mathrm{n}=36)$

\begin{tabular}{lll}
\hline Karakteristik & Jumlah & Persentase \\
\hline Post test & & \\
$\quad$ Stunting & 15 & 42.7 \\
$\quad$ Tidak stunting & 21 & 58.3 \\
\hline Jumlah & 36 & 100 \\
\hline
\end{tabular}

Berdasarkan tabel 3 dapat dilihat sebagian besar responden tidak lagi mengalami stunting semenjak di berikan treatment $(58.3 \%)$.

Table 4

Perkembangan Setelah Treatment Status Stunting berdasarkan Jenis Kelamin $(n=36)$

\begin{tabular}{lllll}
\hline \multirow{2}{*}{ Jenis kelamin } & \multicolumn{4}{c}{ Status Gizi } \\
\cline { 2 - 5 } & \multicolumn{2}{c}{ Stunting } & \multicolumn{2}{c}{ Tidak stunting } \\
\cline { 2 - 5 } & 5 & $25 \%$ & 15 & $75 \%$ \\
\hline Perempuan & 10 & $62.5 \%$ & 6 & $37.5 \%$ \\
Laki-laki & 15 & $42,7 \%$ & 21 & $58,3 \%$ \\
\hline Jumlah & &
\end{tabular}

Berdasarkan tabel 4 dapat dilihat bahwa jenis kelamin perempuan memiliki respon yang lebih baik terhadap treatment di bandingkan dengan jenis kelamin laki-laki dengan besar keberhasilan untuk jenis kelamin perempuan sebesar $75 \%$ dan laki-laki hanya berhasil sebesar $37.5 \%$.

\section{PEMBAHASAN}

\section{Karakteristik responden}

Dari hasil diketahui bahwa jumlah proporsi ibu yang memiliki tinggi badan <150 $\mathrm{cm}$ pada bayi stunting adalah sebesar 52.8\%. Kejadian stunting memiliki hubungan dengan kondisi fisik ibu baduta. Hal ini sesuai dengan hasil penelitian yang dilakukan oleh Nasution (2014) yang menemukan bahwa ibu yang memiliki tinggi badan $150 \mathrm{~cm}$ lebih beresiko memiliki bayi stunting di bandingkan ibu yang memiliki tinggi badan $\geq$ $150 \mathrm{~cm}$ (OR: 2.18, 95\%CI: 1.12-4.23). Penelitian lain yang hasilnya sama dilakukan oleh Rachmi (2016) menemukan bahwa tinggi ibu memiliki hubungan konklusif signifikan terhadap kejadian stunting pada baduta (OR: 2.17, 95\%CI: 1.88-2.51, pvalue: <0.001). Begitu juga dengan yang dilakukan oleh Amin (2014) menemukan bahwa hubungan tinggi badan ibu terhadap kejadian stunting (OR: 2.4, 95\%CI: 1.143.65, p-value: 0.01 ).

Tingkat pendidikan merupakan hal penting yang harus di miliki ibu dikarenakan hal ini dapat mempengaruhi kejadian stunting. Hal tersebut sesuai dengan penelitian yang dilakukan oleh Setiawan (2018) menemukan bahwa adanya hubungan signifikan pendidikan ibu dengan kejadian stunting (OR: 9.9, 95\%CI: 1.2-80.5, p-value: 0.012).

Pekerjaan ibu merupakan aktivitas fisik yang dilakukan dan menunjukkan status ekonomi keluarga. Dari data Departemen Pekerja Umum (2018) menunjukan bahwa jumlah upah minimum regional di Provinsi Bengkulu merupakan 10 besar terendah di tingkat nasional dengan jumlah pendapatan yang rendah. Hal ini dapat menjelaskan bahwa status pekerjaan ibu dapat menunjukkan kondisi ekonomi keluarga yang berpengaruh pada pembelian bahan pangan untuk pemberian nutrisi, termasuk nutrisi 
dalam kehamilan,selama menyusui dan nutrisi yang diberikan pada baduta. Jika nutrisi yangdikonsumsi kurang baik, maka akan berdampak pada bayi, sehingga dapat mempengaruhi proses tumbuh kembang bayi termasuk beresiko terjadi stunting. Hal ini sesuai dengan penelitian yang dilakukan Maisarah (2018) menemukan bahwa adanya pengaruh pekerjaan dengan kejadian stunting dengan nilai p-value: 0.008 .

Pengetahuan ibu merupakan hal yang sangat penting dimiliki seorang ibu, dimana dari hasil penelitian diketahui bahwa sebesar 58.3\% ibu baduta memiliki kemampuan yang kurang. Hal ini memiliki hubungan dengan kejadian stunting. Berdasarkan penelitian yang dilakukan oleh Olsa (2017) menemukan bahwa adanya pengaruh pengetahuan ibu dengan kejadian stunting dengan nilai p-value: <0.001 memiliki pengaruh terhadap kejadian stunting. Hal serupa yang di temukan oleh Agustiningrum (2016) dengan nilai OR: 1.68 dan p-value: 0.043.

Pengetahuan yang kurang dapat mempengaruhi sikap ibu dalam mengkonsumsi makanan yang bergizi dan menjaga kesehatan bayi selama proses kehamilan yang merupakan salah satu tindakan dalam mencegah bayi lahir dengan stunting. Salah satu tindakan yang baik dilakukan ibu adalah dengan menggunakan atau memanfaatkan bahan pangan lokal (makanan tradisional) secara arif dan bijaksana. Penggunaan pangan lokal yang dihasilkan masyarakat setempat secara arif memiliki keuntungan berupa tidak ada efek samping yang negatif. Hal ini sesuai dengan penelitian yang di lakukan oleh Ferguson (2007) dengan menggunakan teknik meta-analysis study menemukan bahwa makanan tradisional tidak memiliki efek yang negatif kepada baduta.

\section{Pengaruh bahan pangan lokal terhadap peningkatan tinggi badan baduta stunting}

Hasil penelitian dari pre-test dan post-test menunjukan hasil yang baik dengan nilai mean pre-test: 69.61 dan mean post-test: 77.16, nilai korelasi > 0.05 (0.846) yang menyatakan bahwa adanya hubungan korelasi yang kuat dalam melakukan treatment weaning pada baduta dan memiliki signifikan ( $p$-value : <0.001).

Dari hasil post-test menunjukan adanya perkembangan tinggi badan semenjak di berikan treatment berupa pemberian makanan tambahan (weaning) ke pada baduta yang mengalami stunting. Selama pemberian makanan tambahan (weaning), makanan pokok baduta berupa ASI tetap diberikan. Perkembangan yang terjadi sebesar $61.1 \%$. Perkembangan bulan pertama pada saat pemberian treatment terjadi perubahan sebesar $8.3 \%$ pada baduta berjenis kelamin perempuan ( 3 orang) dan tidak adanya perubahan status pada baduta laki-laki. Pada bulan ke-2 pemberian treatment pangan lokal, terjadi peningkatan status gizi sebesar $25 \%$ dengan baduta jenis kelamin perempuan sebesar sebanyak 7 orang $(35 \%)$ dan laki-laki sebanyak 2 orang $(12.5 \%)$. Sedangkan di akhir bulan atau bulan ke-3 pemberian treatment terjadi peningkatan sebesar $58.3 \%$ dengan jumlah perempuan sebanyak 15 orang (75\%) dan laki-laki sebanyak 6 orang (37.5\%).

Jenis kelamin bayi merupakan salah satu prediktor akan kejadian stunting. Dimana bayi laki-laki lebih beresiko dengan kejadian stunting jika dibandingkan dengan bayi perempuan. Resiko itu berdasarkan perbedaan besar energi yang dibutuhkan antara laki-laki dan perempuan cukup berbeda. Dimana jenis kelamin lakilaki membutuhkan asupan yang lebih besar jika dibandingkan dengan bayi perempuan. Hal tersebut sesuai dengan penelitian yang dilakukan oleh Hagos (2017) menemukan bahwa adanya hubungan konklusif signifikan jenis kelamin bayi terhadap kejadian stunting yang mana bayi lelaki lebih beresiko 1.34 dibandingkan dengan bayi perempuan (OR: 1.34, 95\% BCI: 1.14-1.57). 
Hasil treatment yang diberikan dari treatment pertama sampai dengan dilakukan post-test memiliki perkembangan yang baik. Dengan melihat hasil perkembangan baduta yang di lihat dari panjang/tinggi badan dengan nilai mean yang terus meningkat, berkorelasi kuat dan memiliki nilai signifikan yang mana semua nilai signifikan di bawah 0.05 .

Dari hasil ini menunjukan bahwa pangan lokal dapat digunakan sebagai salah satu alternatif dalam menurunkan angka kejadian stunting. Pangan lokal ini memiliki gizi yang baik, seperti jagung, dalam 100 gram jagung manis mengandung energi sekitar 35 Kkal, 2,2 gr protein, 0,1 gr lemak, 7,4 gram karbohidrat hingga $8 \mathrm{mg}$ vitamin C. Untuk belut memiliki mengandung berupa 300 kkal per 100 gram, vitamin A 7093 IU per 100 gram, kaya dengan beberapa mineral seperti kalsium dan fosfor, asam lemak omega 3 dan asam lemak omega 6, dan Vitamin B12. Sedangkan pada ikan nila memilki kandungan berupa omega-3, asam DHA, dan Vitamin D. Semua pangan ini diolah menjadi bubur (untuk jagung) dan sup (untuk ikan). Agar dapat mudah dicerna oleh baduta dan tidak merusak sistem pencernaan. Dengan kandungan gizi yang baik dan proses yang baik menjadi suatu hal yang bernilai positif untuk asumsi gizi dalam proses perbaikan status gizi. Selain hal tersebut, harga yang relatif murah dan mudah di dapatkan merupakan salah satu point lebih dalam pemanfaatan pangan lokal secara arif tanpa bahan pengawet yang sangat aman untuk baduta.

Sesuai dengan Gerakan Nasional Pencegahan Stunting, Pilar ke-4 mengenai Nutritional Food Security, dan dilihat dari segi ekonomi bahwa masyarakat Indonesia merupakan kelas ekonomi menengah ke bawah, penerapan penggunaan pangan lokal merupakan alternatif yang baik dalam menurunkan angka stunting dengan nilai gizi yang cukup dan harga yang relatif murah dan tidak memiliki efek negatif. Sehingga mudah untuk di peroleh, di olah dan di konsumsi. Juga tidak menimbulkan komplikasi terhadap bayi. (TNP2K, 2018).

Berdasarkan tindakan penanganan baduta yang memiliki status gizi yang buruk, terapi yang tepat digunakan adalah terapi pangan dengan menggunakan pangan alami atau masakan tradisional. Selama pemberian terapi pangan ini baduta tetap mendapatkan ASI. Dengan kebutuhan nutrisi per hari yang harus diberikan berupa energi dengan range: 80-220 kkal, protein dengan range: 1-6 gram, vitamin c sebanyak $50 \mathrm{mg}$, dan asam folat sebanyak $5 \mathrm{mg}$. Dengan pemberian asupan nutrisi melalui terapi pangan, status nutrisi akan semakin baik. Hal ini dapat dilihat dari grafik perkembangan yang di lakukan. Dimana terapi pangan di lakukan selama tiga bulan atau 90 hari. Berdasarkan teori ini, asupan nutrisi pada treatment yang dilakukan dalam riset ini sudah memenuhi standar baku. Dikarenakan kandungan yang diberikan dalam treatment mengandung nutrisi yang baik dan sesuai dengan standart, seperti kandungan jagung dalam 100 gram jagung manis mengandung energi sekitar $35 \mathrm{Kkal}, 2,2$ gr protein, 0,1 gr lemak, 7,4 gram karbohidrat hingga $8 \mathrm{mg}$ vitamin C. juga kandungan belut dalam 100 gram meliputi: energi sebesar $300 \mathrm{kkal}$, protein sebesar 18.7 gram, vitamin A sebesar 7093 IU, kalsium, fosfor, omega 3 dan 6, dan vitamin B12. Hal ini menunjukan adanya pengaruh pangan terhadap panjang/tinggi baduta. (Direktorat Bina Gizi, 2011).

Treatment dalam pemberian weaning pada baduta yang memiliki stunting menggunakan pangan kearifan lokal bersifat positif. Hal ini didukung dengan program lain yang telah dilakukan sebelum diberikan terapi pangan pada baduta. Program tersebut adalah melakukan pelatihan tentang pengenalan dan pengolahan pangan lokal yang dibutuhkan baduta (seperti bubur jagung tim dan sup belut sawah/sup ikan nila), pada kader, pada ibu baduta. Pemantauan serta pengontrolan program pangan ini 
dilakukan selama 90 hari penelitian.

Penelitian yang dilakukan oleh Supadmi (2008) menemukan dan membuktikan bahwa pemberian pangan berupa kalori, protein, mineral dan vitamin (tepung dari nasi, tempe, ayam, lele, bayam dan wortel) dapat meningkat tinggi baduta dengan mean 82.8 sebelum melakukan treatment menjadi 84.3 sesudah treatment.

\section{SIMPULAN}

Terdapat perubahan tinggi badan yang bermakna pada baduta sebelum dan setelah dilakukan intervensi

Intervensi pemberian weaning kearifan pangan lokal yang diberikan dalam penelitian ini sangat efektif dalam menaikkan tinggi badan baduta stunting

Peneliti menyimpulkan bahwa secara klinis intervensi efektif dalam meningkatkan tinggi badan baduta stunting. Peneliti menganggap bahwa intervensi ini memiliki manfaat yang baik dalam upaya peningkatan perubahan stunting status melalui kenaikan tinggi badan baduta stunting, meskipun kenaikannya tidak terlalu tinggi.

\section{SARAN}

Program yang tepat, pelatihan kader, pemantauan dan pengontrolan program diperlukan agar dapat menurunkan angka pravelensi stunting. Sehingga data menjadi lebih akurat dan dapat menjadi bahan pertimbangan untuk kebijakan kesehatan yang berkelanjutan.

\section{DAFTAR PUSTAKA}

Agustininggrum, Tia. (2016). Hubungan Karakterisitik Ibu dengan Kejadian Stunting di Wiayah Kerja Puskesmas Wonosari I. Jurnal UNISA

Amin, N. A. (2014). Faktor Sosio-Demografi dan Tinggi Badan Orang Tua serta Hubungannya dengan Kejadian Stunting pada Balita Usia 6-23 Bulan. Jurnal Gizi dan Dietetik, 2(3)

BKKBN. (2018). Waspadai Ledakan Penduduk. BKKBN. Indonesia

Departemen Pekerjaan Umum. (2018). Profil Departemen Pekerjaan Umum Propinsi Bengkulu

Dinas Kesehatan Propinsi Bengkulu. (2018). Profil Dinas Kesehatan Propinsi Bengkulu Tahun 2018

Direktorat Bina Gizi. (2011). Petunjuk Teknik Tatalaksana Anak Gizi Buruk II

Ferguson, Elaine. (2007). Traditional Foods vs. Manufactured Baby Foods. Nutritional Quality and Safety Journal.

Hagos, Saifu. (2017). Spatial Heterogeneity and Risk Factors Forstunting among Children Under age Five in Ethiopia: A Bayesian Geo-Statistical Model. Plos One Journal

Kementerian Kesehatan Republik Indonesia. (2018). Situasi Balita Pendek (Stunting) di Indonesia. Infodatin

Maisarah, F. U. (2018). Hubungan Status Pekerjaan, Tingkat Pendapatan Keluarga, Tingkat Pengetahuan Ibu tentang Gizi dan Pemberian ASI Ekslusif terhadap Status Gizi Balita. UNISA

Martorell R., Horta B.L., Adair L.S., Stein A.D., Richter L., Fall C.H. (2010). Weight Gain in the First Two Years of Life is an Important Predictor of Schooling Outcomes in Pooled Analyses from Five Birth Cohorts from Low and Middle Income Countries. Journal of Nutrition 140, 348-354 
Nasution, D. (2014). Berat Badan Lahir Rendah (BBLR) dengan Kejadian Stunting pada Anak Usia 6-24 Bulan. Jurnal Gizi Klinik Indonesia, 11

Olsa, E. D. (2017). Hubungan Sikap dan Pengetahuan Ibu terhadap Kejadian Stunting pada Anak Baru Masuk Sekolah Dasar di Kecamanatan Nanggalo. Jurnal Fakultas Kesehatan: Unand

Rachmi, C. N. (2016). Stunting, Underweight and Overweight in Children Aged 2.0-4.9 Years in Indonesia: Prevalence Trends and Associated Risk Factors. Plos One Journal

Riskesdas. (2013). Riset Kesehatan Dasar (RISKESDAS) 2013. Laporan Nasional 2013, 1-384. https://doi.org/1

Senbanjo IO. (2011). Prevalence of and Risk Factors for Stunting among School Children and Adolescents in Abeokuta, Southwest Nigeria. Health Population Nutrition Journal, 364-70

Setiawan, E. (2018). Faktor-Faktor yang Berhubungan dengan Kejadian Stunting pada Anak Usia 24-59 Bulan di Wilayah Kerja Puskesmas Andalas Kecamatan Padang Timur Kota Padang Tahun 2018. Jurnal Fakultas Kesehatan: Unand

Supadmi, S. (2008). Pengaruh Pemberian Makanan Tambahan pada Balita Kurang Energi (KEP). PGM 2008

TNP2K. (2017). 100 Kabupaten atau Kota Prioritas untuk Intervensi Anak Kerdil. Tim Nasional Percepatan Penanggulangan Kemiskinan: Jakarta

TNP2K. (2018). Gerakan Nasional Pencegahan Stunting dan Kerjasama Kemitraan Multi Sektor.

WHO. (2015). Stunting Brief. World Health Organization 